\title{
Effect of Nutrients and Plant Growth Regulator on Yield and Biochemical Parameter of Tomato (Lycopersicum esculentum L.)
}

\author{
Mr. Umesh T.Sattigeri ${ }^{1}$, Dr. Eugenia P. Lal ${ }^{2}$, Shivalingappa \\ S.Bangi ${ }^{3}$, Mr.Manjunath Tallur ${ }^{4}$, Santosh S.Bangi ${ }^{5}$ \\ ${ }^{I}(($ Dept. of Biological Sciences, Sam Higginbottom Institute of Agriculture, Technology and Sciences, India) \\ ${ }^{2}$ (Dept. of Biological Sciences, Sam Higginbottom Institute of Agriculture, Technology and Sciences, India) \\ ${ }_{3}^{3}$ (Dept. of Biological Sciences, Sam Higginbottom Institute of Agriculture, Technology and Sciences, India) \\ ${ }^{4}$ (University of Agricultural Sciences, Dharwad ,India) \\ ${ }^{5}$ (University of Horticultural Sciences, Bagalkot,India)
}

\begin{abstract}
The experiment was carried out during Rabi season 2013-14, Department of Biological Sciences, SHIATS, Allahabad (U.P.) the influence of organic, inorganic nutrients forms and plant growth regulators on various morphological growth, biochemical traits, and yield components in tomato (Lycopersicum esculetium. L.) The experiment was consisting of two organic i.e., FYM and vermicompost at two different concentrations, one $P$-solubilizer nutrients viz., $\mathrm{KNO}_{3}$ and $\mathrm{FeSO}_{4}$ and plant growth regulators viz., salicylic acid and $\mathrm{GA}_{3}$ with three replications. Significant differences were observed for various morphological, biochemical and yield attributes due to the application of organic, nutrients and plant growth regulators. The plant height increased significantly due to the application of salicylic acid $(50 \mathrm{ppm})$ and P-solubilizer $(2.5 \mathrm{~kg} / \mathrm{ha})$. The morphological traits viz., number of branches, in leaf increased significantly due to application of organic, nutrients and plant

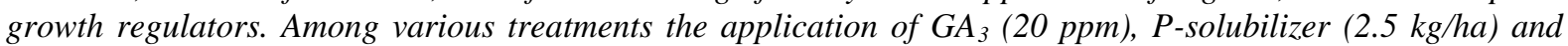
vermicompost (2 t/ha) were effective in increase plant height, leaves, fruit diameter, \& number of fruit. The biochemical parameters tested, like chlorophyll content was significantly higher with $\mathrm{GA}_{3}(20 \mathrm{ppm})$ followed by vermicompost ( 2 and 1 t/ha).
\end{abstract}

Key words: $F Y M, G A_{3}$, Lycopene, PGR, salicylic acid.

\section{Introduction}

Tomato (Lycopersicon esculentum L. Mill.) is one of the most important vegetable crops grown widely all over the world. It is a self-pollinated crop and is a member of Solanaceous family with $2 \mathrm{n}=24$ chromosomes. Peru Equator region is considered to be the center of origin (Rick 1969). . In India, it ranks second among vegetables next to potato in terms of area and production. Tomato universally treated as 'Protective Food', is being extensivelygrown as annual plant. Tomato is a rich source of minerals, vitamins, \& organic acids (healthy acid). Tomatoes are important source of Lycopene, minerals, Vitamin-A, B \& also excellent source Of Vitamin-C. Tomato is also rich in medicinal value. The pulp and juice are digestible and blood purifier. Frasher $\boldsymbol{e t}$ al. (1991) reported decreased cancer risk with the intake of tomatoes. This neutraceutical effect of tomato is attributed to 'lycopene' a major carotenoids present in tomatoes. Tomato being an important vegetable crop and photo periodically insensitive and can be cultivated throughout the year. Nowadays Rainfall patterns have drastically changed due to climate change resulting in erratic distribution between the seasons. Added to this, depleting has become a matter of great concerns both water resources and agricultural purpose. Under this context, it is necessary to evolve to a suitable technology and identified good crop management practices for increasing water use efficiency. Cultivation of tomato is limited in the state and less work has been done on these aspects. Therefore, it is the right time to give more emphasis on the evaluation of organic, other chemicals for growth performance, yield potential and quality improvement.

\section{Materials And Methods}

The experiment was carried out during Rabi season on Tomato (Lycopersicum esculentum L.) Cv. Bhima of 2013-14, Department of Biological Sciences, SHIATS, Allahabad, in the experiment was conducted in RBD plot design consisting of 8 treatment combinations with 3 replications and was laid out with the different treatments allocated randomly in each replication.

Treatments details.

$\mathrm{T}_{0}-$ control

$\mathrm{T}_{1}-\mathrm{FYM}(5$ ton/ha)

$\mathrm{T}_{2}$ - Vermicompost (1t/ha)

$\mathrm{T}_{3}$ - Phosphorus solubilizer 
$\mathrm{T}_{4}-\mathrm{FeSO}_{4}(0.5 \%)$

$\mathrm{T} 5-\mathrm{KNO}_{3}(0.5 \%)$

$\mathrm{T}_{6}$ - Salicylic acid (50 ppm)

$\mathrm{T}_{7}-\mathrm{GA}_{3}(20 \mathrm{ppm})$

\section{Observation Recorded}

\subsection{Growth parameters}

2.1.1 Plant Height:

The plant height was measured from ground level to the terminal growing point of the main stem at 30 , 60 , and 90 DAT. The average plant height was expressed in centimeter $(\mathrm{cm})$.

\subsubsection{Number of leaves per plant:}

Total number of leaves per plant was counted from plants at 30,60 and 90 DAT and at harvest and mean was worked out and expressed as number of leaves per plant.

\subsubsection{Number of branches per plant:}

The number of branches arising on the main stem in the plant was recorded at 30, 60 and 90 DAT. The mean number of branches per plant was worked out and expressed in number.

\subsection{Yield parameter}

\subsubsection{Number of fruit per plant:}

The number of fruits harvested from plants in each treatment was counted from different pickings and average was worked out and expressed as number of fruits per plant.

\subsubsection{Fresh weight of fruits (gm):}

Weight of 5 earlier randomly tagged plant was weighted from which total weight of fruit per plant was calculated and express in grams

\subsubsection{Fruit diameter $(\mathrm{cm})$ :}

The diameter of fruits was measured by using measuring tape at the widest point of the fruit. Average of three fruits diameter was worked out in $\mathrm{cm}$.

\subsection{Biochemical observation}

\subsubsection{Estimation of Chlorophyll a \& b:-}

Estimation of chlorophyll (a\&b) was done by methods given by Prakash Rao (1998) The chlorophyll content in the leaves was estimated by weighing $1 \mathrm{gm}$ of fresh leaves and was grounded with pestle and mortar. The $10 \mathrm{ml}$ of $80 \%$ acetone was added to and this much quantity of samples was taken in test tubes and was kept overnight. Next to that those samples are homogenized at $3000 \mathrm{rpm}$ for 15 minutes. The absorbance of the samples was recorded at $645 \mathrm{~nm}$ and $663 \mathrm{~nm}$ respectively.

Chlorophyll $\mathrm{mg} / \mathrm{g}$ fresh weight can be calculated by the formula given below:

$\mathrm{Chl} \mathrm{a}(\mathrm{mg} / \mathrm{g})=\left[\left\{\left(12.7 \times \mathrm{ABS}_{663}\right)-\left(2.69 \times \mathrm{ABS}_{645}\right)\right\} \times V\right] / 1000 \times W$

Chl b $(\mathrm{mg} / \mathrm{g})=\left[\left\{\left(22.9 \times \mathrm{ABS}_{645}\right)-\left(4.68 \times \mathrm{ABS}_{663}\right)\right\} \times V\right] / 1000 \times W$ Where;

$\mathrm{ABS}_{663}=$ Absorbance at $663 \mathrm{~nm}$

$\mathrm{ABS}_{645}=$ Absorbance at $645 \mathrm{~nm}$

$\mathrm{V}=$ Volume of acetone used

$\mathrm{W}=$ Weight of sample taken

\subsubsection{Lycopene Content}

The fruit sample was cut into small pieces and macerated in a warring blender. Two grams of pulp was taken in a $100 \mathrm{ml}$ stopper conical flask containing $5 \mathrm{ml}$ of 0.05 percent (w/v) BHA in acetone, $5 \mathrm{ml}$ of 95 per cent ethanol, $10 \mathrm{ml}$ of hexane. The contents were stirred for 15 minutes in a magnetic stirrer. Later it was kept on orbital shaker in ice for 30 minutes. Then $3 \mathrm{ml}$ of demonized water was added and shaken for another 15 minutes. It was allowed for phase separation. The absorbance was measured at $503 \mathrm{~nm}$ in a spectrophotometer. Lycopene content (mg/100g fr.wt) was calculated by using the formula given by Ranganna (1977).

$$
\text { Lycopene }=\quad \frac{3.1206 \times \text { OD of sample } \mathrm{x} \text { Volume made up } \mathrm{x} \text { Dilution }}{\text { Weight of sample } \mathrm{x} 1000}
$$

\subsection{Statistical analysis}

Data recorded on different aspects of crop, viz; growth, yield attributes and yield were tabulated and subjected to statistical analysis as per Gomez and Gomez, 1976. Significance of difference between treatment 
means was tested through ' $F$ ' test and the critical difference $(C D)$ was worked out wherever ' $F$ ' value was found to be significant for treatment effect.

\section{Results And Discussion}

\subsection{Observation on growth parameters}

3.1.1Plant height $(\mathbf{c m})$

At 30 DAT maximum plant height was found in $T_{6}$ (72.6) followed $T_{5}$ (71.8) minimum was found in $\mathrm{T}_{7}$ (66.2). At 60 DAT maximum plant height was found in $\mathrm{T}_{6}(93.3)$ followed by $\mathrm{T}_{5}(92.3)$ and minimum was found in $\mathrm{T}_{0}$ (80.90). At 90 DAT maximum plant height was found in $\mathrm{T}_{6}(95.4)$ followed by $\mathrm{T} 5$ (95.0) and minimum was found in $T_{4}$ (85.3). Similar results were found in French bean by Deka and Das (1975).

\subsubsection{Number of leaves}

At 30 DAT maximum number of leaves was found in $\mathrm{T}_{6}$ (84.6) and minimum was found in $\mathrm{T}_{0}$ (34.6). At 60 DAT maximum number of leaves was found in $\mathrm{T}_{7}$ (143.3) and minimum was found in $\mathrm{T}_{0}$ (61.67). At 90 DAT maximum number of leaves was found in $\mathrm{T}_{7}$ (138.3) and minimum was found in $\mathrm{T}_{0}(52.6)$. Studied the effect of GA and salicylic acid on common bean and reported an increase in plant height due to GA treatment in pigeonpea, Sosa et al. (1999).

\subsubsection{No of branches}

At 30 DAT maximum number of branches was found in $\mathrm{T}_{6}$ (13.7) and minimum was found in $\mathrm{T}_{0}$ (9.03). At 60 DAT maximum number of branches was found in $\mathrm{T}_{6}(20.2)$ and minimum was found in $\mathrm{T}_{0}(12.4)$. At 90 DAT maximum number of branches was found in $\mathrm{T}_{6}(24.40)$ and minimum was found in $\mathrm{T}_{0}(17.2)$. Reported opined was foliar application of plant growth regulators showed significant increase in number of branches and plant height in black gram Prakash et al. (2003).

\subsection{Observation on Biochemical parameters}

\subsubsection{Chloraphyll ' $a$ '}

In table 2 showed was significant at different effect of organic and inorganic nutrients forms and plant growth regulator on maximum chlorophyll (a) was found in $\mathrm{T}_{6}(2.5)$ and minimum was found in $\mathrm{T}_{0}(1.5)$. Indicated was with an increase in Fe level, there was increase in total (a\&b) chlorophyll content in green gram Prakash Rao (1998).

\subsubsection{Chloraphyll ' $b$ '}

In table 2 showed that significant at different effect of organic and inorganic nutrients forms and plant growth regulator on chlorophyll (b) maximum was found in $\mathrm{T}_{6}$ (1.76) and minimum was found in $\mathrm{T}_{0}(1.14)$. Prakash Rao (1998) indicated that with an increase in Fe level, there was increase in total (a\&b) chlorophyll content in green gram.

\subsubsection{Lycopene content}

Lycopene content (g) maximum lycopene content was found in $\mathrm{T}_{6}(4.5)$ and minimum was found in $\mathrm{T}_{0}$ (3.5). Lycopene content (mg/100g fr.wt) was calculated by using the formula given by Ranganna (1977).

\subsection{Yield parameters}

\subsubsection{Number of fruits}

Maximum number fruit per plant was found in $\mathrm{T}_{6}$ (23.5) and minimum was found in $\mathrm{T} 0$ (10.8).Similar results observed that the foliar spray of salicylic acid resulted in maximum grain yield cowpea by Pramodkumar et al.(1991).

\subsubsection{Fruit weight per plant}

Maximum fruit weight/plant $(\mathrm{g})$ was found in $\mathrm{T}_{6}(560.9)$ and minimum was found in $\mathrm{T}_{0}(442)$. Studied the same effect of salicylic acid in green gram and reported that there was increase in yield and yield components due to these chemicals Saishankar (2001).

\subsubsection{Fruit diameter $(\mathrm{cm})$}

Maximum fruits diameter $(\mathrm{cm})$ was found in $\mathrm{T}_{6}$ (24.4) and minimum was found in $\mathrm{T}_{0}$ (14.2). Similar results observed that in foliar spray of salicylic acid results maximum grain yield in cowpea Pramodkumar $\boldsymbol{e t}$ al. (1991). 
Table: 1. Effect of nutrients and plant growth regulator on growth parameters at different stages in tomato (Lycopersicum esculentum L.)

\begin{tabular}{|c|c|c|c|c|c|c|c|c|c|}
\hline \multirow[t]{2}{*}{ Treatment } & \multicolumn{3}{|c|}{ Plant height $(\mathrm{cm})$} & \multicolumn{3}{|c|}{ Number of leaves per plant } & \multicolumn{3}{|c|}{ Number of branches per plant } \\
\hline & $30 \mathrm{DAT}$ & $60 \mathrm{DAT}$ & $90 \mathrm{DAT}$ & $30 \mathrm{DAT}$ & $60 \mathrm{DAT}$ & $90 \mathrm{DAT}$ & $30 \mathrm{DAT}$ & $60 \mathrm{DAT}$ & $90 \mathrm{DAT}$ \\
\hline $\mathrm{T}_{0}$ & 67.2 & 80.9 & 83.9 & 34.6 & 61.6 & 52.6 & 9.03 & 12.4 & 17.2 \\
\hline $\mathrm{T}_{1}$ & 67.5 & 82.9 & 84.6 & 42.3 & 72.3 & 73.3 & 10.7 & 13.6 & 18.1 \\
\hline $\mathrm{T}_{3}$ & 68.8 & 88.0 & 90.5 & 84.0 & 92.6 & 118.3 & 11.5 & 17.1 & 20.5 \\
\hline $\mathrm{T}_{4}$ & 70.4 & 90.9 & 82.2 & 58.0 & 103.3 & 82.0 & 12.4 & 18.1 & 23.2 \\
\hline $\mathrm{T}_{7}$ & 66.2 & 81.3 & 83.0 & 64.0 & 143.3 & 138.3 & 12.8 & 17.9 & 20.1 \\
\hline S. Ed. $( \pm)$ & 0.891 & 0.76 & 1.180 & 3.548 & 4.359 & 6.347 & 1.036 & 0.906 & 0.914 \\
\hline C.D.(5\%) & 1.91 & 1.64 & 2.435 & 7.324 & 8.998 & 13.101 & 2.137 & 1.869 & 1.887 \\
\hline
\end{tabular}

Table: 2. Effect of organic and inorganic nutrients forms and plant growth regulator on Biochemical and Yield parameters in tomato.

\begin{tabular}{|c|c|c|c|c|c|c|}
\hline Treatments & Chlorophyll a & Chlorophyll b & Lycopene & No. of fruits & Fruit weight (g) & $\begin{array}{l}\text { Fruit diameter } \\
(\mathrm{cm})\end{array}$ \\
\hline $\mathrm{T}_{0}$ & 1.5 & 1.1 & 3.5 & 10.8 & 442.0 & 14.20 \\
\hline $\mathrm{T}_{1}$ & 1.6 & 1.2 & 3.6 & 12.2 & 452.3 & 19.26 \\
\hline $\mathrm{T}_{2}$ & 1.7 & 1.4 & 3.8 & 15.3 & 466.3 & 21.13 \\
\hline $\mathrm{T}_{3}$ & 1.7 & 1.5 & 3.8 & 16.2 & 486.3 & 22.20 \\
\hline $\mathrm{T}_{4}$ & 1.9 & 1.6 & 4.1 & 18.0 & 491.2 & 21.60 \\
\hline $\mathrm{T}_{5}$ & 2.3 & 1.6 & 4.3 & 20.2 & 514.1 & 22.63 \\
\hline $\mathrm{T}_{6}$ & 2.5 & 1.7 & 4.5 & 23.5 & 560.9 & 24.40 \\
\hline $\mathrm{T}_{7}$ & 1.5 & 1.5 & 3.8 & 21.4 & 458.8 & 18.13 \\
\hline S. Ed. $\mathbf{( \pm )}$ & 0.273 & 0.115 & 1.093 & 1.064 & 1.079 & 1.050 \\
\hline C.D. $(\mathbf{5 \%})$ & 0.564 & 0.237 & 2.256 & 2.197 & 2.227 & 2.167 \\
\hline
\end{tabular}

\section{Conclusion}

On the basis of single trial experiment, To study the effect of different growth regulators $\mathrm{GA}_{3}(20 \mathrm{ppm})$, and salicylic acid (50 ppm), FYM and PSB on growth, yield, quality and physiological parameters of tomato. It is concluded that treatment with salicylic acid $(50 \mathrm{ppm})$ Showed improved growth, yield and quality of tomato over other treatment.

\section{Acknowledgements}

I great thankful to my parents Timmanna Sattigeri, Yellavva Sattigeri and my whole family members for their guidance, inspiring, co-operation, encouragement during the preparation of this manuscript.

\section{References}

[1]. Faser, G. E., Beeson, L. and Phillips, R.L., Diet and lung cancer in California, Seventh-Day Adventists, Amer. J. epidemiology.133,1991,683-693.

[2]. Prakash rao, J.S., Growth and mineral nutrients composition of six cultivars of green gram grown at normal and deficient levels of iron supply. Madras Agricultural Journal, 85(2), 1998, 96-99.

[3]. Pramodkumar, D., Dube and Chauhan, V.S., Effect of salicylic acid on growth, developmentand some biochemical aspects of soyabean (Glycine max L. Merrill). Indian Journals of Plant Physiology, 4, 1999, 327-330.

[4]. Rick, C. M., Origin of cultivated tomato, current status of the problems. Abstract XI International Botanical Congress,pp. 1969,180.

[5]. Sosa, M.E., Ortega, D., M.L., Larque, S.A., Ortiz M.E. and San, M.C.R.,Interaction of photon flux density with gibberellic and salicylic acids on common bean plants. Revista Chapingo Serie Infenieria Agropecuaria, 2(1) 1999, 47-51.

[6]. Prakash, M., Kumar, J.S., Kannan, K., Kumar, M.S. and Ganesan, J., Effect of plant growth regulators on growth physiology and yield of black gram. Legumes Research. 26(3), 2003, 183-187.

[7]. Saishankar, S.,Influence of plant growth regulators, chemicals and the nutrients in green gram (Vigna radiate L.). M.Sc. (Agri.) Thesis, University of Agricultural Sciences, Dharwad 2001.) 